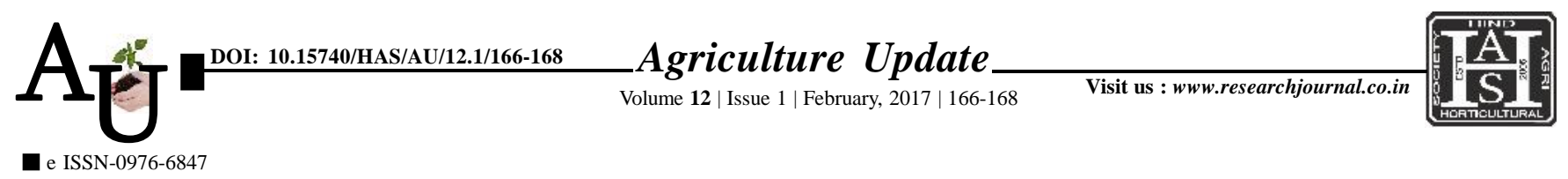

\title{
Research article: Communication behaviour of banana growers in Delta region of Tamil Nadu
}

\section{J. MEENAMBIGAI, D. PRATHAPSINGH AND C. THATCHINAMOORTHY}

SUMMARY : Banana is the most important food crops and they are the stable food for at least 400 million people. Banana is mostly grown in a traditional way by the majority of farmers, but success of banana cultivation depends on the communication behaviour. Main aim of this study to analyse the communication behaviour of banana growers, the study was taken up in Thiruvidaimaruthur Taluk in Thanjavur district of Tamil Nadu. A sample size of 120 farmers cultivating banana formed the sample for the study. Data were gathered with the help of pre-tested interview schedule. Percentage analysis, cumulative frequency method, correlation co-efficient and multiple regressions were the statistical techniques used to analyse the data. The results showed nearly half of the banana growers were found to have moderate level of overall communication behaviour. Hence, it is necessary to improve the credibility of gross root level extension services and to create awareness among the banana growers about the modem communication gadgets and train them on the aspects of accessibility to computers and internet.

How to cite this article : Meenambigai, J., Prathapsingh, D. and Thatchinamoorthy, C. (2017). Communication behaviour of banana growers in Delta region of Tamil Nadu. Agric. Update, 12(1): 166-168; DOI : 10.15740/ HAS/AU/12.1/166-168.
Author for correspondence :

\section{THATCHINAMOORTHY}

Department of

Agricultural Extension,

Faculty of Agriculture,

Annamalai University,

CHIDAMBRAM (T.N.)

INDIA

Email:tmthatchupeaceful

@gmail.com

See end of the article for

authors' affiliations 